\title{
Potential application of thermo-sensitive hydrogels for controlled release of phenacetin
}

\author{
Snežana S. llić-Stojanović ${ }^{1}$, Ljubiša B. Nikolić ${ }^{1}$, Vesna D. Nikolić ${ }^{1}$, Jela R. Milić ${ }^{2}$, Slobodan D. Petrović ${ }^{3}$, \\ Goran M. Nikolić ${ }^{4}$, Agneš J. Kapor ${ }^{5}$ \\ ${ }^{1}$ University of Niš, Faculty of Technology, Leskovac, Serbia \\ ${ }^{2}$ University of Belgrade, Faculty of Pharmacy, Belgrade, Serbia \\ ${ }^{3}$ University of Belgrade, Faculty of Technology and Metallurgy, Belgrade, Serbia \\ ${ }^{4}$ University of Niš, Faculty of Medicine, Niš, Serbia \\ ${ }^{5}$ University of Novi Sad, Faculty of Sciences, Department of Physics, Novi Sad, Serbia
}

\begin{abstract}
Over the past years, many scientific research studies have been focused on thermo-sensitive hydrogels containing $N$-isopropylacrylamide (NIPAM) as a monomer. The NIPAM based hydrogels with 20 mol\% 2-hydroxypropyl methacrylate (HPMet) were synthesized using ethylene glycol dimethacrylate as a cross-linker. The characterization of xerogel and phenacetin using Fourier transform infrared (FTIR) spectroscopy and Scanning electron microscopy (SEM)confirm the performed synthesis with satisfactory purity as well as loading of phenacetin into hydrogel. The swelling transport mechanism at simulated physiological conditions $\left(\mathrm{pH} 2.20\right.$ and 7.40 at $\left.37^{\circ} \mathrm{C}\right)$ is described by the time-independent kinetics. The potential application of synthesized hydrogels for the controlled release of phenacetin as a model drug was investigated at simulated physiological conditions by HPLC method.
\end{abstract}

Keywords: thermo-sensitive hydrogel; $N$-isopropylacrylamide; 2-hydroxypropyl methacrylate, phenacetin.

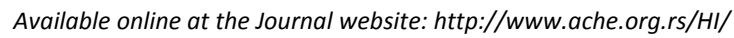

\author{
SCIENTIFIC PAPER \\ UDC 544.773.432:543.544.5:661.12
}

Hem. Ind. 66 (6) 831-839 (2012)

doi: 10.2298/HEMIND120222089I
Hydrogels are cross-linked three-dimensional polymer networks, which may absorb a significant amount of water and swell several thousand times more than a dry gel mass. They are soft, wet and pliable materials, compatible with most living tissues and with a wide range of potential biomedical applications. They swell in water but do not dissolve in it $[1,2]$. A special class of hydrogels, which are called "intelligent" or "stimuli-responsive", exhibits a significant volume transition in response to small changes in the environmental conditions like temperature, $\mathrm{pH}$, ultrasound, electric field, magnetic field, light, pressure, glucose, etc. Their ability to swell and deswell according to environmental conditions makes them interesting for use as drug delivery systems [3-7]. During the last 30 years hydrogels have become very interesting drug carriers for a controlled delivery due to their biocompatibility and resemblance to biological tissues [4,8-12].

Thermo-sensitive hydrogels exhibit volume phase transitions at critical temperatures, i.e., lower critical solution temperatures (LCST) or upper critical solution temperatures (UCST). LCST polymers exhibit a swellingto-shrinking transition with increasing the temperature (negative thermo-sensitive hydrogels), while the UCST

Correspondence: S. Ilić-Stojanović, University of Niš, Faculty of Technology, Bulevar oslobođenja 124, 16000 Leskovac, Serbia.

E-mail: ilic.s.snezana@gmail.com

Paper received: 22 February, 2012

Paper accepted: 30 July, 2012 polymers undergo the opposite transitions (positive thermo-sensitive hydrogels) [13-15]. Poly( $N$-isopropylacrylamide), $\mathrm{p}$ (NIPAM), is one of the most widely used thermo-sensitive polymers. It has a hydrophilic amide group and a hydrophobic isopropyl group. p(NIPAM) has LCST of around $32{ }^{\circ} \mathrm{C}[2,14]$. Hydrophilic 2-hydroxypropyl methacrylate (HPMet) has excellent biocompatibility with living tissues and good tolerance by the cells. HPMet is widely used in immunocytochemical processes [16], as well as in the production of contact lenses [17]. Some investigations are based on its properties as a drug carrier or in separation processes [18-22].

Non-steroidal anti-inflammatory drugs (NSAID) are drugs with analgesic (but non-narcotics), antipyretic and anti-inflammatory effects. Phenacetin, $\mathrm{N}$-(4-etoxyphenyl)-acetamide, was selected from the group of NSAID as a model drug in the study of hydrogel poly $(N$ -isopropylacrylamide-co-2-hydroxypropyl methacrylate), $\mathrm{p}$ (NIPAM-co-HPMet) being potential carriers for the controlled delivery [21,22]. Phenacetin was chosen as one part of the wider investigation of the selected nonsteroidal anti-inflammatory drugs: paracetamol, which is a precursor of phenacetin, then ibuprofen, naproxen, and piroxicam. Recent studies show the results of a series of formulations of phenacetin with interpolymer carboxyvinylpolymer complexes with poly(ethylene oxide) [23-25], carbopol [26] or methylcellulose [27], as well as the comparative determination of a particle size of phenacetin bulk powder [28]. 
The aims of this study are the synthesis of thermosensitive $\mathrm{p}$ (NIPAM-co-HPMet) hydrogels by free radical copolymerization, the synthesis of phenacetin, their characterization by using Fourier transform infrared spectroscopy (FTIR), scanning electron microscopy (SEM) and swelling behavior and the investigation of the potential applications of obtained hydrogels for a controlled release of phenacetin as a model drug.

\section{EXPERIMENTAL}

\section{Reagents}

$\mathrm{N}$-Isopropylacrylamide (NIPAM) 99\%, 2-hydroxypropyl methacrylate (HPMet) $96.5 \%$ and 2,2'-azobis(2-methylpropionitrile) (AZDN) 98\%, from Acros, USA; ethylene glycol dimethacrylate (EGDM) 97\%, Fluka, CH; acetone, Centrohem, Belgrade, RS; methanol, Unichem, Belgrade, RS; phenacetin, synthesized in the laboratory of the Faculty of Technology, Leskovac.

\section{Synthesis of p(NIPAM-co-HPMet)}

$\mathrm{p}$ (NIPAM-co-HPMet) were synthesized by radical polymerization of NIPAM with $20 \mathrm{~mol} \%$ of HPMet in acetone (as solvent) by using the initiator (AZDN) and a varied concentration of cross-linker $(1,1.5,2$ and 3 mol\% EGDM) under the temperature regime: $0.5 \mathrm{~h}$ at $70{ }^{\circ} \mathrm{C}, 2 \mathrm{~h}$ at $80{ }^{\circ} \mathrm{C}, 0.5 \mathrm{~h}$ at $85^{\circ} \mathrm{C}$. The temperature range from 70 to $85{ }^{\circ} \mathrm{C}$ was chosen to activate the initiator and the polymerization process as well because of the full utilization of the initiator at the temperature increase. P(NIPAM), with 2 mol\% of EGDM as a crosslinker was synthesized under the same conditions. The obtained gels were extracted by methanol in order to remove all non-reacted water insoluble compounds, monomers and oligomers. Swollen gels were dried to constant mass at $40^{\circ} \mathrm{C}$.

\section{Synthesis of phenacetin}

The procedure of phenacetin synthesis is performed in two steps (Figure 1). At the first stage of the reaction between $p$-aminophenol and anydrous acetic, $p$-acetaminopheol is obtained. In the second step, the conversion of acetaminopheol (as the type of the William- son ether synthesis) using sodium ethanoate in the mixture of $p$-ethyl iodide and hydroxyacetamide is carried out to $\mathrm{N}$-4-etoxyphenyl acetamide. The raw product was recrystallized from ethanol with the addition of active carbon. The obtained phenacetin was filtered and dried in air.

\section{Characterization methods}

Fourier transform infrared spectroscopy (FTIR)

The samples were recorded with $\mathrm{KBr}$ technique on a BOMEM MB-100 (Hartmann \& Braun, Canada) at wavelengths of $4000-400 \mathrm{~cm}^{-1}$.

\section{Scanning electron microscopy (SEM)}

The morphology of lyophilized hydrogels and samples with loaded phenacetin was investigated on a JEOL Scanning Microscope JSM-5300. The samples were first coated by gold/palladium alloy (15/85).

\section{Swelling behavior}

The swelling behavior of xerogels were carried out in distilled water (at 20 and $40{ }^{\circ} \mathrm{C}$ ) and in simulated physiological conditions ( $\mathrm{pH} 2.20$ and 7.40 at $37^{\circ} \mathrm{C}$ ) and monitored gravimetrically. The swelling ratio, $\alpha$, was calculated according to the equation:

$\alpha=\frac{m-m_{0}}{m_{0}}$

where $m_{0}$ is the mass of xerogel, and $m$ is the mass of swollen gel at time $t$.

\section{Loading of phenacetin}

Xerogel of $p$ (NIPAM-co-HPMet) was swelled in the phenacetin solution, $40 \mathrm{mg} / \mathrm{cm}^{3}$, in a $80 / 20 \%$ methanol/distilled water mixture for $48 \mathrm{~h}$.

\section{The released phenacetin}

The swollen gel of $p$ (NIPAM-co-HPMet) was soaked with $7 \mathrm{~cm}^{3}$ of solutions at simulated physiological conditions ( $\mathrm{pH} 2.20$ and 7.40) and the amount of released phenacetin was monitored by high-pressure liquid chromatography (HPLC) for $24 \mathrm{~h}$ at a temperature of $37^{\circ} \mathrm{C}$. The analysis was performed by HPLC on an Agilent

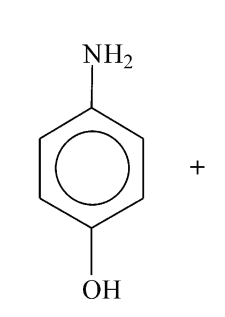

4-aminophenol

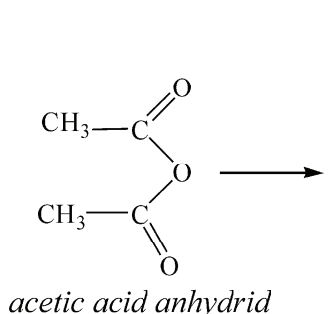

N-(4-hydroxyphenyl)acetamide (paracetamol)

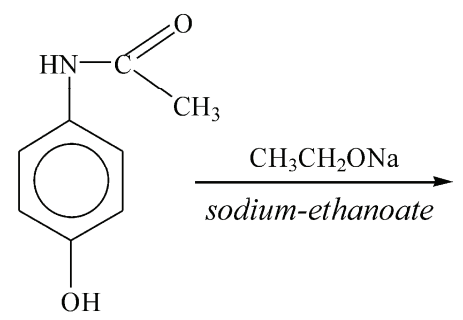

$\mathrm{N}-(4-e t o x y p h e n y l)-a c e t a m i d e$
(phenacetin)

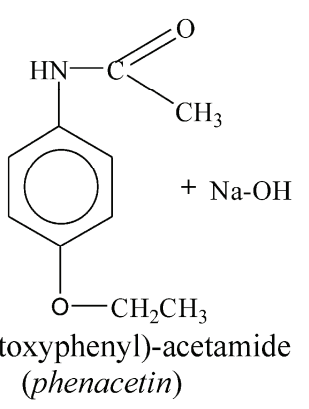

Figure 1. Schematic form of phenacetin synthesis. 
1100 Series device under the following conditions: detector DAD 1200, detection wavelength $205 \mathrm{~nm}$, column ZORBAX XDB-C18, $250 \mathrm{~mm} \times 4.6 \mathrm{~mm}, 5 \mu \mathrm{m}$, eluent methanol, eluent flow $1 \mathrm{ml} / \mathrm{min}$, sample injection volume $20 \mu \mathrm{l}$, column temperature $25^{\circ} \mathrm{C}$.

\section{RESULTS AND DISCUSSION}

\section{FTIR Analysis}

In the FTIR spectrum of NIPAM monomer the following bands were observed: valence vibrations of $\mathrm{C}=\mathrm{C}$ double bond at $1622 \mathrm{~cm}^{-1}$, symmetric valence vibrations, $\mathrm{v}_{\mathrm{s}}$, of $\mathrm{CH}_{3}$ groups at $2875 \mathrm{~cm}^{-1}$, asymmetric valence vibrations, $\mathrm{v}_{\mathrm{as}}$, of $\mathrm{CH}_{3}$ groups at $2970 \mathrm{~cm}^{-1}, \mathrm{v}_{\mathrm{as}}$ of $\mathrm{CH}_{2}$ group at $2933 \mathrm{~cm}^{-1}$ and $\mathrm{v}_{\text {as }}$ of $\mathrm{CH}$ from vinyl group at $3072 \mathrm{~cm}^{-1}$. The valence absorption of $\mathrm{N}-\mathrm{H}$ bond from the amide structure was observed at $3284 \mathrm{~cm}^{-1}$.

In the spectrum of HPMet monomer the following bands were observed: valence vibrations of $\mathrm{C}-\mathrm{O}$ at 1296 and $1173 \mathrm{~cm}^{-1}$, valence vibrations of $\mathrm{C}=\mathrm{C}$ double bond at $1638 \mathrm{~cm}^{-1}$, vibrations of $\mathrm{C}=\mathrm{O}$ double bond from ester at $1720 \mathrm{~cm}^{-1}$, vibrations of $\mathrm{C}-\mathrm{H}$ bond: $\mathrm{v}_{\mathrm{s}}$ of $\mathrm{CH}_{3}$ at $2894 \mathrm{~cm}^{-1}$ and $v_{\text {as }}$ of $\mathrm{CH}_{3}$ at $2980 \mathrm{~cm}^{-1}$, and valence vibration of $\mathrm{OH}$ group at about $3450 \mathrm{~cm}^{-1}$.

In the FTIR spectrum of $p$ (NIPAM-co-HPMet) xerogel with $20 \mathrm{~mol} \%$ of HPMet, there appears to be no absorption bands that could originate from the double $\mathrm{C}=\mathrm{C}$ bond, which indicates that the synthesis is performed by the initiation of radicals (Figure 2). The following bands were observed: vibrations of the double $\mathrm{C}=\mathrm{O}$ bond from amide at $1652 \mathrm{~cm}^{-1}$ and the double $\mathrm{C}=\mathrm{O}$ bond from ester at $1728 \mathrm{~cm}^{-1}$, vibrations of $\mathrm{C}-\mathrm{H}$ bond from $-\mathrm{CH}_{3}$ and $-\mathrm{CH}_{2}$ groups at 2973, 2930 and $2878 \mathrm{~cm}^{-1}$. Valence vibrations of lateral $\mathrm{NH}$ and $\mathrm{OH}$ group were observed at 3304 and $3437 \mathrm{~cm}^{-1}$, respectively.

FTIR Spectrum of phenacetin indicates that phenacetin was successfully obtained with the satisfying purity. The following bands that originated from the aromatic ring were observed: valence vibration of $\mathrm{C}-\mathrm{H}$ bond at $3073 \mathrm{~cm}^{-1}$, out-of-plane deformation vibrations of $\mathrm{C}-\mathrm{H}$ bonds at $838,826,785$ and $743 \mathrm{~cm}^{-1}$ and valence vibration of $\mathrm{C}=\mathrm{C}$ bond with four characteristic bands at: $1608,1556,1509$ and $1481 \mathrm{~cm}^{-1}$. The valence vibration of C-O-C bond can be observed at $1245 \mathrm{~cm}^{-1}$ $\left(v_{a s}\right)$ and $1048 \mathrm{~cm}^{-1}\left(v_{s}\right)$. The valence vibration of a double $\mathrm{C}=\mathrm{O}$ bond of secondary amide at $1658 \mathrm{~cm}^{-1}$, the vibrations of $\mathrm{C}-\mathrm{H}$ bond of $-\mathrm{CH}_{3}$ groups: $v_{\mathrm{s}}$ at 2886 and 2850, $V_{\text {as }}$ at 2981 and $2927 \mathrm{~cm}^{-1}$ and the valence absorption of $\mathrm{NH}$ bond from the secondary amide at 3432 and $3285 \mathrm{~cm}^{-1}$ were observed.

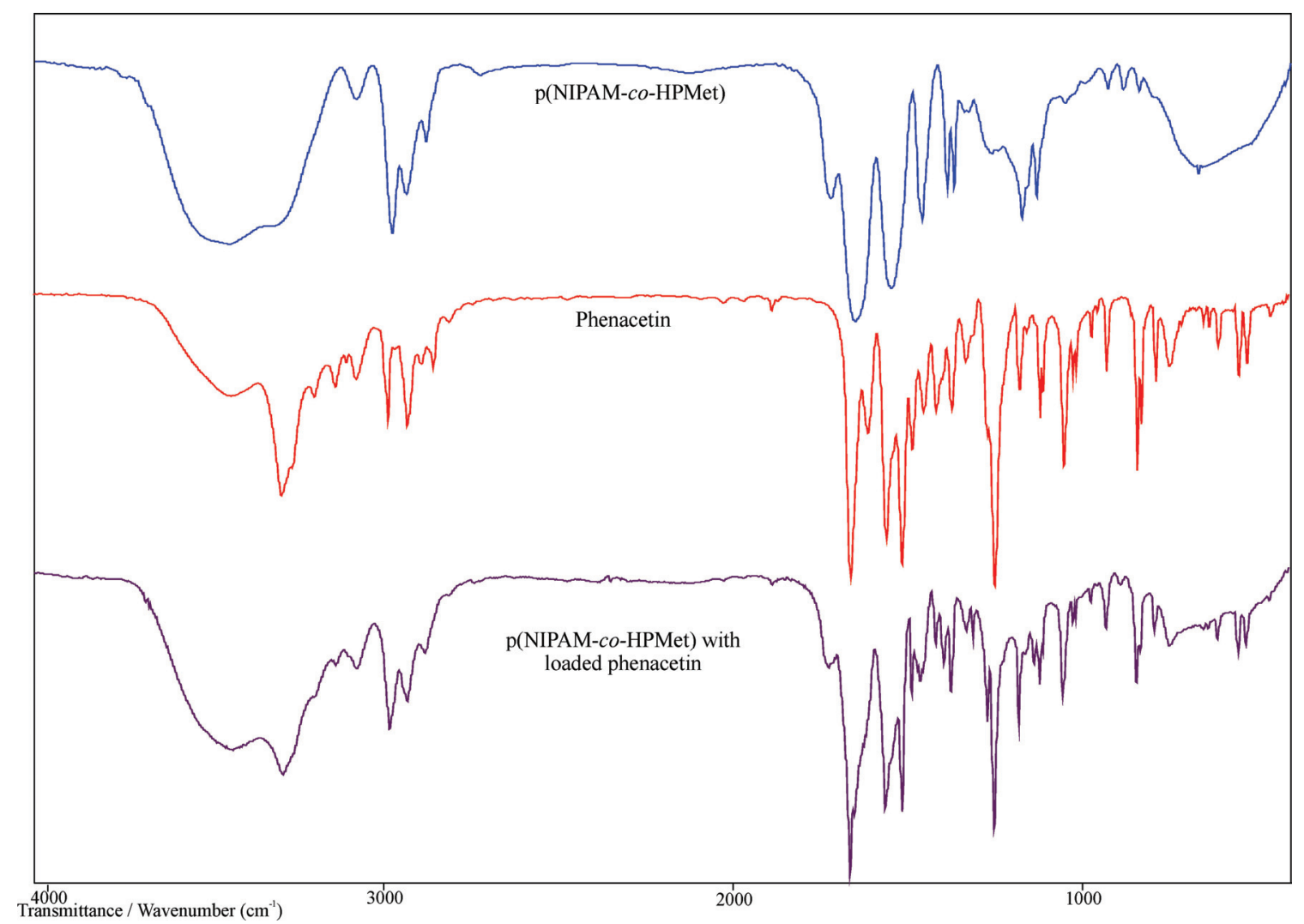

Figure 2. FTIR Spectra of (NIPAM-Co-HPMet), phenacetin and p(NIPAM-co-HPMet) hydrogel with loaded phenacetin. 
The FTIR spectrum of xerogels with loaded phenacetin indicates that phenacetin was successfully inserted into the hydrogels cavity by forming intermolecular noncovalent bonds. The following bands that originated from xerogel were observed: valence vibrations of the double $\mathrm{C}=\mathrm{O}$ bond from ester at $1719 \mathrm{~cm}^{-1}$ and of the double $\mathrm{C}=\mathrm{O}$ bond from amide at $1660 \mathrm{~cm}^{-1}$, which were moved for 9 and 8 units to the lower frequency side, respectively. Valence vibrations of $\mathrm{OH}$ group were observed at $3441 \mathrm{~cm}^{-1}$, which was moved for 4 units to a higher frequency side. The following bands that originated from phenacetin were observed: valence vibrations of $\mathrm{NH}$ and $\mathrm{C}=\mathrm{O}$ bond of secondary amide at 3286 and $1660 \mathrm{~cm}^{-1}$ which were moved for 1 and 2 units to a higher frequency side. Shifts of these bonds may indicate the interaction of the drug loaded into the hydrogel. Considering the fact that those shifts are very small, the interaction between hydrogel and phenacetin are of a noncovalent type.

\section{SEM Analysis}

SEM micrographs of swollen and then lyophilized samples of p(NIPAM-co-HPMet) hydrogel with 0.5 mol\% EGDM for a) pure hydrogel and b) with loaded phenacetin are presented in Figure 3.

The hydrogel morphology has a porous surface. The observed structure of hydrogel was changed after the treatment of the phenacetin solution and its loading into the hydrogel structure.

\section{Swelling behavior of p(NIPAM-co-HPMet) hydrogels}

Swelling behavior for a series of hydrogels at 20 and $40{ }^{\circ} \mathrm{C}$ depending on the time and EGDM content is demonstrated in the authors' previous studies [22]. It was found that the swelling ratio for $p$ (NIPAM-co-HPMet) hydrogels with 20 mol\% HPMet increases ex-

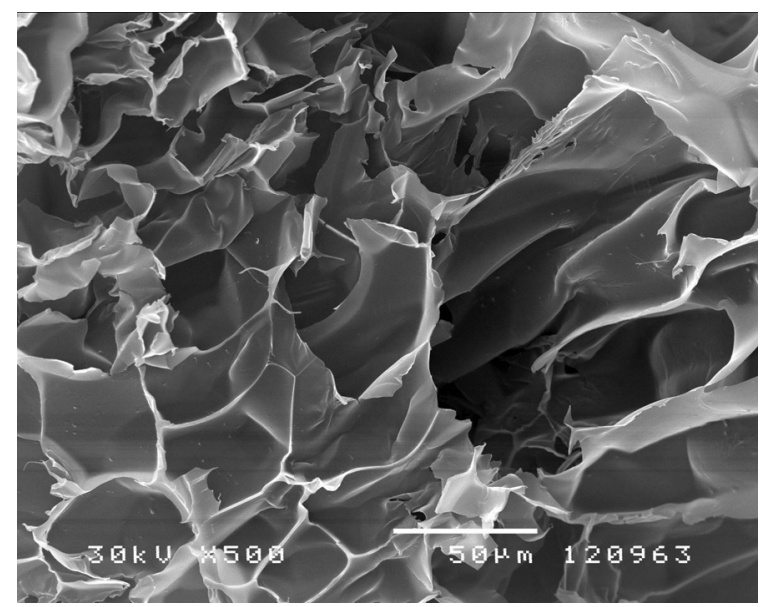

(a) tensively during the first $6 \mathrm{~h}$. Along with the increase of the cross-linker content, the swelling ratio decreases. The reason is the formation of a denser network due to large amounts of the cross-linker. Polymer chains are more fixed and less able to absorb water. In contrast, when a small quantity of cross-linker is present, the length of the polymer chains between two knots is larger, the network is able to expand and absorb a greater amount of water. By adjusting the amount of cross-linkers used in the gels, the synthesis can affect the water absorption ability, and hence the swelling ratio can be controlled.

In order to study the water transport mechanism from $p$ (NIPAM-co-HPMet) hydrogels with different cross-linker contents, Fick's Equation was applied to fit the experimental data [5]:

$$
F=M_{t} / M_{e}=k t^{n}
$$

where $M_{t} / M_{e}$ is the fractional sorption, $M_{t}$ is the amount of the water absorbed at time $t, M_{e}$ is the maximum amount of the absorbed water; $k$ is a constant incorporating characteristic of the polymer network system, $n$ is the diffusion exponent. The exponents $n$ and $k$ are values determined from the slope and intercept of the plots of In $M_{t} / M_{e}$ versus In $t$ for $p$ (NIPAM-co-HPMet) hydrogels at different EGDM contents. If $n$ is less than 0.5 , the swelling process is controlled by the Fickian diffusion mechanism. If $n$ varies between 0.5 and 1 , the diffusion and polymer relaxation control the swelling process and indicates an anomalous diffusion mechanism, which is known as non-Fickian diffusion. The values of $n$ greater than 1 are described as type III (Case III) or Super Case II. Figure 4 shows the dependence of $n$ versus EGDM cross-linker content, according to $\mathrm{p}$ (NIPAM-co-HPMet) hydrogels swelling at 20 and 40 ${ }^{\circ} \mathrm{C}$. It is clear from the analysis that with the increase of

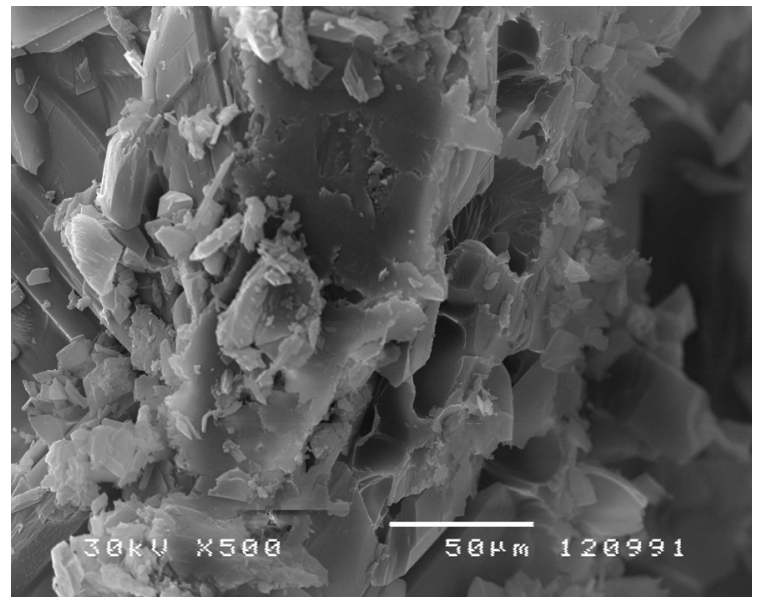

(b)

Figure 3. SEM Micrographs of lyophilized p(NIPAM-co-HPMet) samples with 0.5 mol\% of EGDM: a) pure and b) with loaded phenacetin. 
the EGDM content in the hydrogel structure, the diffusion release kinetic exponent $n$ decreases from 0.80 to 0.53 at $20^{\circ} \mathrm{C}$. This proves that the swelling transport mechanism is the non-Fickian type diffusion, and the swelling process is controlled by water diffusion and relaxation of polymer chains. Also, in the samples with $1 \mathrm{~mol} \%$ of EGDM ( $n$ is 0.80 ) the relaxation of polymer chains in relation to diffusion of water dominates, because it is closer to Case II, when $n$ is equal to 1 . A similar result is obtained for $\mathrm{p}$ (NIPAM-co-HPMet) hydrogel with a similar molar ratio of HPMet monomer (21 mol\%) produced by the gamma irradiation method of Nizam El-Din [20], where the achieved diffusion exponent is 0.56 . The diffusion release kinetic exponent $n$ decreases from 1.27 to 1.16 at $40{ }^{\circ} \mathrm{C}$. This proves that the swelling transport mechanism is described as Case III or Zero-order, time-independent kinetics characterized by a linear mass uptake with time [6].

Thermo-sensitivity of the obtained p(NIPAM-co-HPMet) gels was also confirmed by examining the swelling at the temperature of $40{ }^{\circ} \mathrm{C}$ so that the increase in temperature decreases the swelling ratio, which was expected by the presence of phase transitions. The dependence of the equilibrium-swelling ratio, for $\mathrm{p}$ (NIPAM-Co-HPMet) hydrogels with $0.5,1,1.5$, 2 and 3 mol\% of EGDM at 20 and $40{ }^{\circ} \mathrm{C}$ is shown in Figure 5. Hydrogels with a higher cross-linking ratio swell less ( $1 \mathrm{~g}$ of gel with 3 mol\% EGDM can absorb nearly $2 \mathrm{~g}$ of water at $40^{\circ} \mathrm{C}$ ) compared to the hydrogels with a minor cross-linking ratio (1 $\mathrm{g}$ of gel with 0.5 mol\% EGDM can absorb nearly $38 \mathrm{~g}$ of water at $20^{\circ} \mathrm{C}$ ). While the temperature increases, the contraction of the network occurs and there is an active squezzing, along with the free diffusion of water molecules, due to the swollen hydrogel collapse. After copolymerization of NIPAM with comonomer HPMet, the LCST changed from 32 (for homopolymer pNIPAM) to $34{ }^{\circ} \mathrm{C}$ (for copolymer $\mathrm{p}($ NIPAM-co-HPMet)), which is closer to the physiological body temperature [22].

The diffusion coefficient $D$, was calculated from the equation:

$\frac{M_{t}}{M_{e}}=\left(\frac{4}{\pi^{0,5}}\right)\left(\frac{D t}{l^{2}}\right)^{0,5}$

where $I$ is the thickness of the dried sample. The initial phase of swelling to $60 \%$ was used for the calculation [29]. By applying logarithm to Eq. (3), a straight line dependence between $\ln \left(M_{\mathrm{t}} / M_{\mathrm{e}}\right)$ and In $t$ can be obtained. The calculated values of equilibrium swelling ratio, $\alpha$, diffusion exponent, $n$, and the diffusion coefficient, $D$, to test the swelling behavior of hydrogels p(NIPAM-Co-HPMet) in simulated physiological conditions at $37{ }^{\circ} \mathrm{C}$ at pH 2.20 and 7.40 are shown in Table 1.

The presented data show similar values of equilibrium swelling ratio of hydrogels at $\mathrm{pH} 2.20$ and 7.40 solutions at $37{ }^{\circ} \mathrm{C}$, as well as the similarity of swelling in distilled water at $40^{\circ} \mathrm{C}$.

\section{The released phenacetin}

The content and amount of the released phenacetin from hydrogels depending of the $\mathrm{pH}$ value is carried out by HPLC method. The dependence of the peak area, $A$ (mAUs), on the phenacetin concentration, $c$ $\left(\mathrm{mg} / \mathrm{cm}^{3}\right)$ is linear for the concentration up to 0.05 $\mathrm{mg} / \mathrm{cm}^{3}$. For linear dependence the following equation applies:

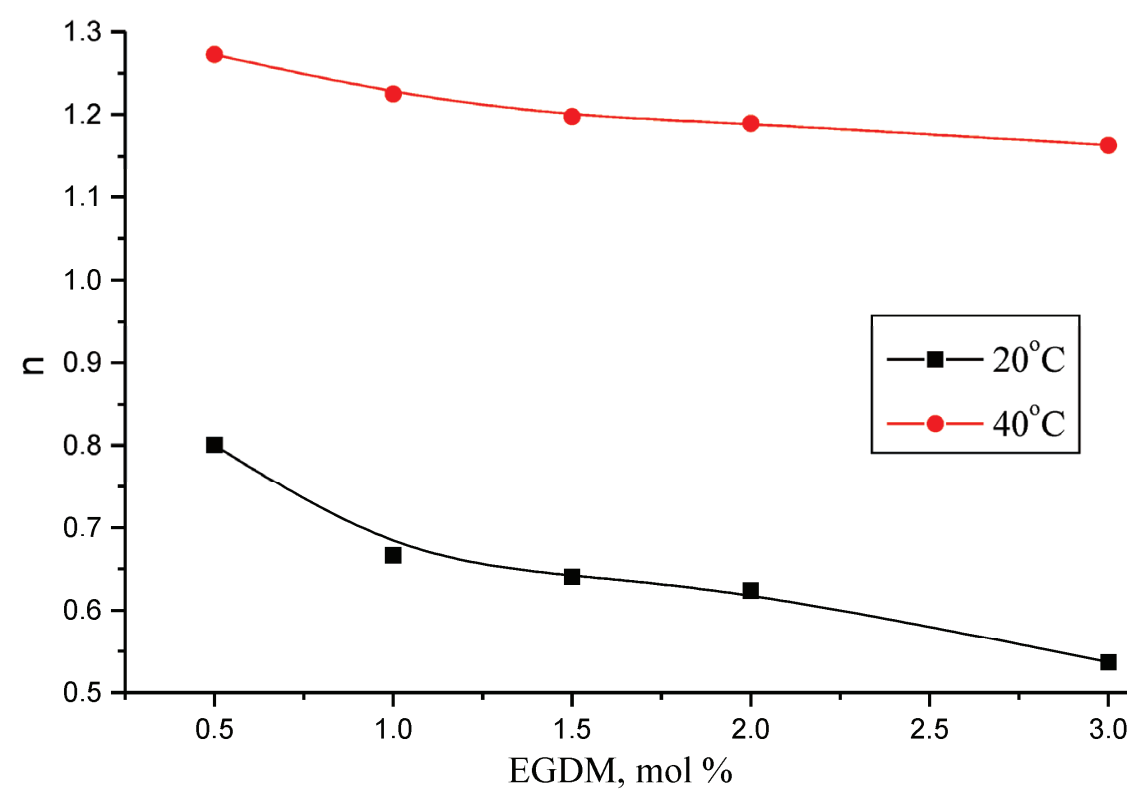

Figure 4. Dependence of diffusion exponent, $n$, versus EGDM cross-linker content in p(NIPAM-co-HPMet) hydrogels at 20 and $40{ }^{\circ} \mathrm{C}$. 


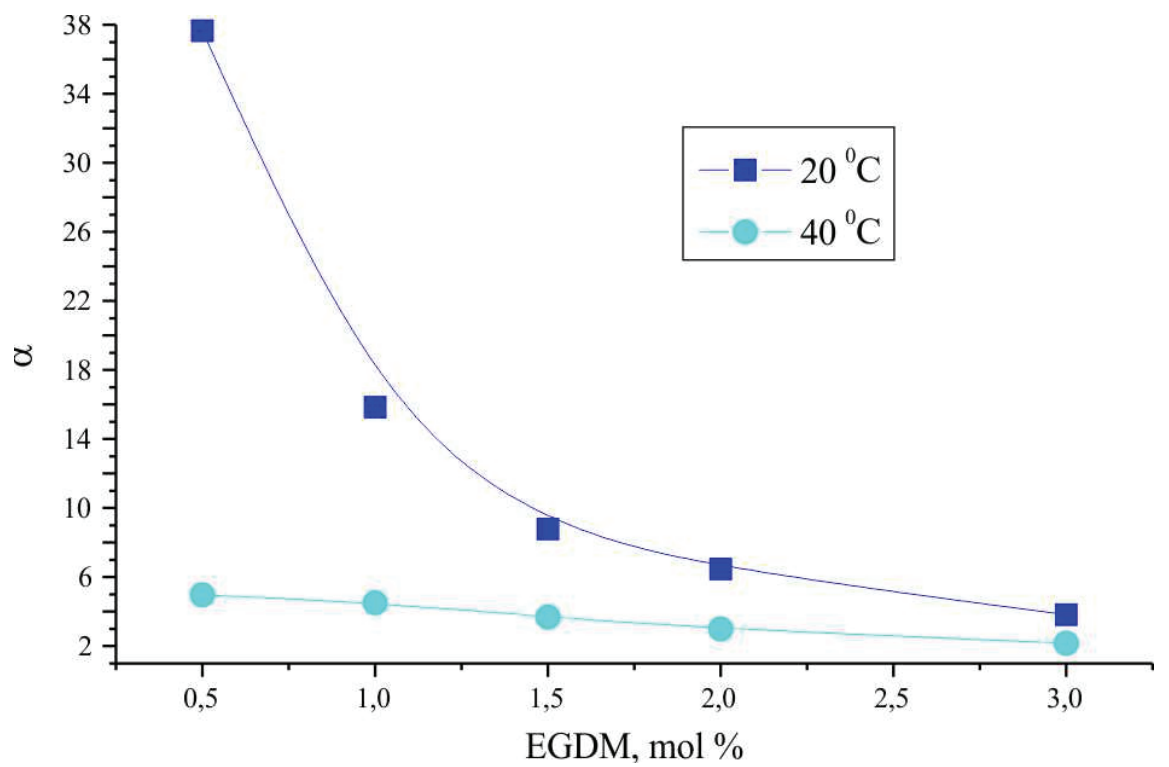

Figure 5. Temperature dependence of equilibrium-swelling ratio, $\alpha$, for p(NIPAM-co-HPMet).

Table 1. The equilibrium swelling ratio and kinetic parameters at $37^{\circ} \mathrm{C}$ and $\mathrm{pH} 2.20$ and $\mathrm{pH} 7.40$ for $\mathrm{p}$ (NIPAM-co-HPMet) hydrogels.

\begin{tabular}{lccccc}
\hline EGDM content, mol\% & Swelling ratio, $\alpha$ & $n$ & $k \times 10^{3} / \mathrm{min}^{-1 / 2}$ & $R^{2}$ & $D \times 10^{7} / \mathrm{cm}^{2} \mathrm{~min}^{-1}$ \\
\hline 0.5 & \multicolumn{7}{c}{$\mathrm{pH} \mathrm{2.2}$} \\
1 & 5.814 & 1.501 & 59.27 & 0.942 & 0.20729 \\
1.5 & 4.042 & 1.443 & 1.04 & 0.965 & 0.08468 \\
2 & 3.066 & 1.423 & 2.49 & 0.965 & 0.02759 \\
3 & 2.462 & 1.342 & 1.62 & 0.979 & 0.03031 \\
\hline & 1.598 & 1.287 & 1.96 & 0.971 & 0.48575 \\
\hline 0.5 & & & & \\
1 & 5.917 & 1.309 & 1.87 & 0.975 & 469.8 \\
1.5 & 4.208 & 1.266 & 2.35 & 0.974 & 393.7 \\
2 & 3.122 & 1.244 & 2.56 & 0.943 & 464.9 \\
3 & 2.505 & 1.237 & 2.55 & 0.974 & 479.3 \\
\hline
\end{tabular}

$c=\frac{A-97.195}{96912.449}$

The result of the phenacetin amount released from $\mathrm{p}$ (NIPAM-co-HPMet) hydrogels at $\mathrm{pH} 2.20$ and 7.40 at $37{ }^{\circ} \mathrm{C}$ during one day are presented in Figures $6 a$ and $6 b$, respectively.

The obtained results in the first $24 \mathrm{~h}$ show that the slightly largest amount of phenacetin was released at $\mathrm{pH} 7.40$ (70-90\% of the absorbed amount), compared to the amount of the released phenacetin at $\mathrm{pH} 2.20$ (50-65\%). It can be observed that the hydrogel with the lowest cross-linker content at $37{ }^{\circ} \mathrm{C}$ released the largest amount of phenacetin $(272.2 \mathrm{mg} / \mathrm{g}$ xerogel, or $90.34 \%$ of total loaded mass). This release behavior may be related to the hydrogel swelling behavior and a weak $\mathrm{H}$-bonding interaction between phenacetin and chains of the hydrogel polymer network. At physiological temperature $\left(37^{\circ} \mathrm{C}\right)$, which is higher than LCST, this intermolecular $\mathrm{H}$-bonding was broken and the drug releases from the hydrogel. Thus, the results are consistent with the achieved equilibrium swelling degrees of synthesized hydrogels. The release profiles showed alower released amount of phenacetin at both $\mathrm{pH}$ values as the EGDM concentration was increased owing to the higher network density and a small available free volume between the chains. On the other hand, as the EGDM content decreased more phenacetin was released from the hydrogel, which could be explained on the basis of the swelling behavior of hydrogels, as a function of the EGDM content. The amount of the released phenacetin proportionally decreases with the increase of the cross-linking density of gels. Calculated kinetic parameters of the released paracetamol (Table 2) 


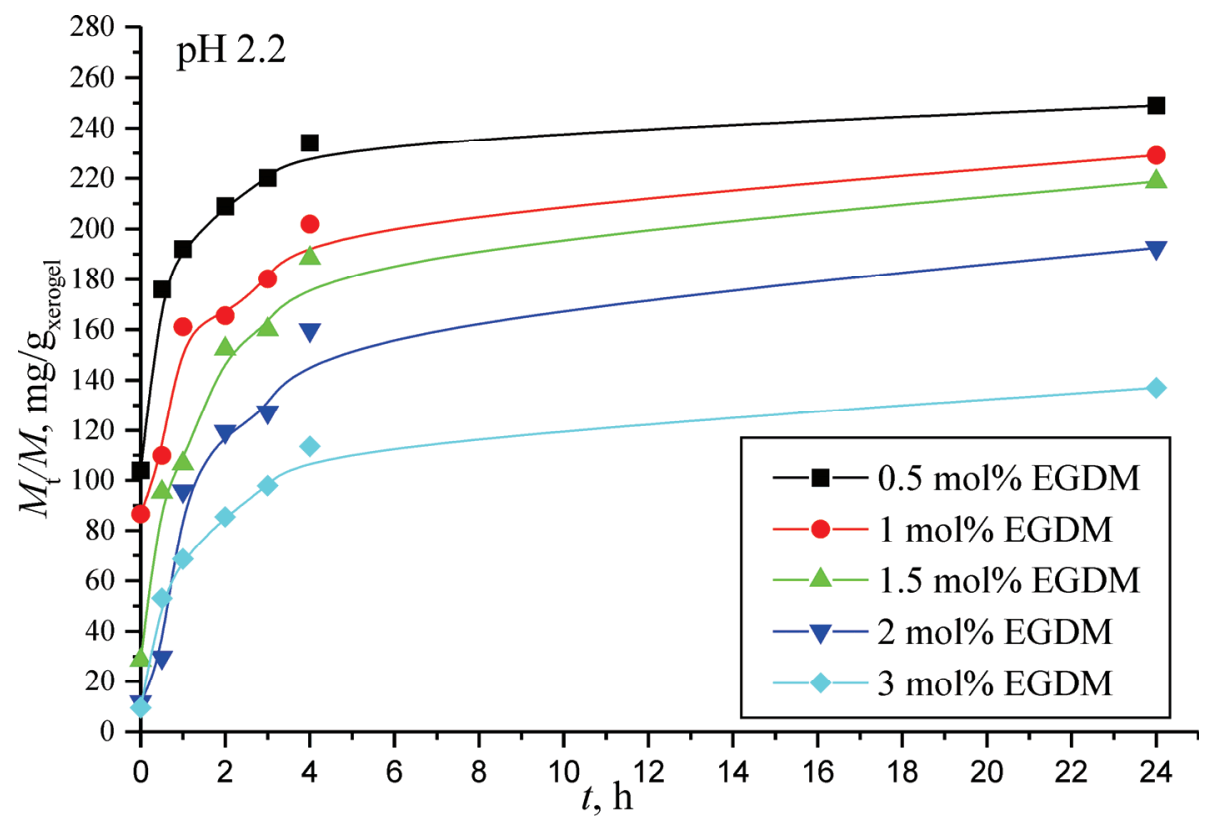

(a)

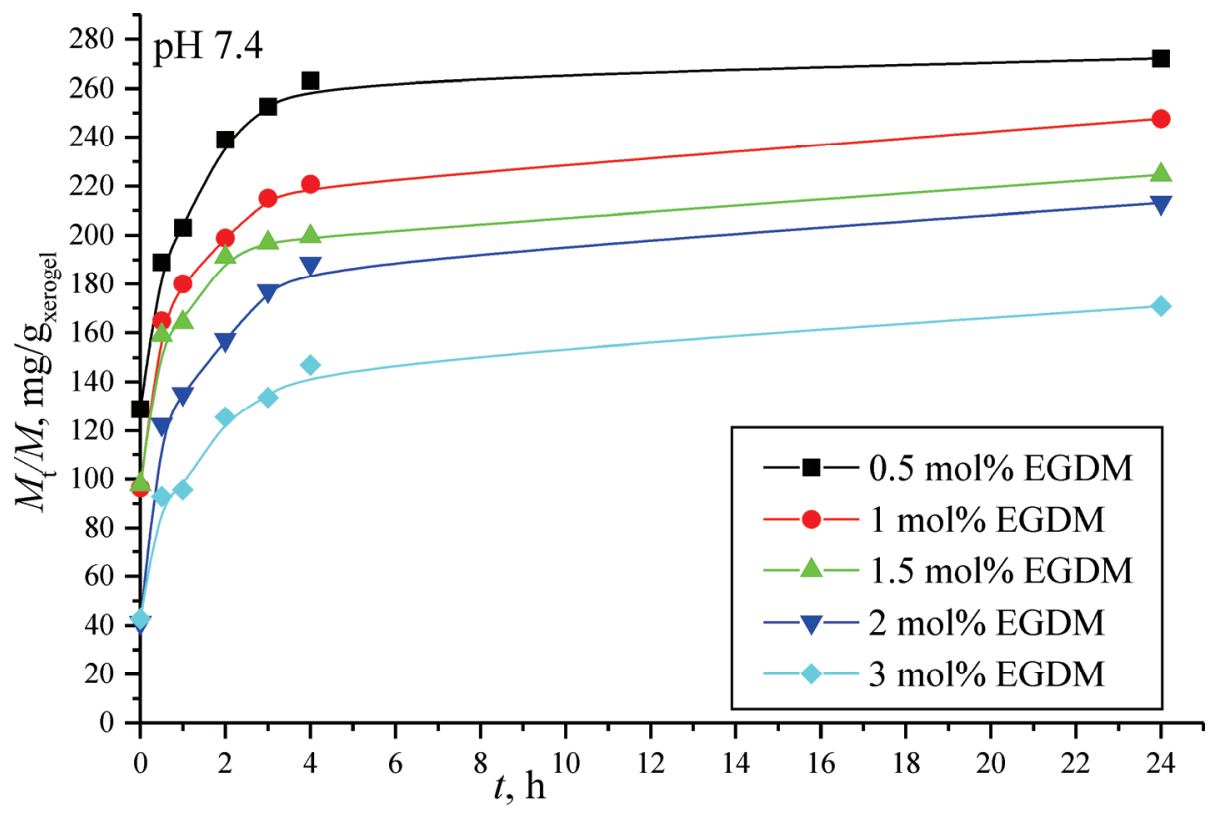

(b)

Figure 6. The phenacetin release from p(NIPAM-co-HPMet) at $37^{\circ} \mathrm{C}$ in simulated physiological conditions: a) pH 2.20 and b) pH 7.40.

show that this process followed Fick's law of diffusion on both $\mathrm{pH}$ values. In addition, the p(NIPAM-co-HPMet) hydrogels prepared in this investigation may be used as an efficient drug carrier of NSAID, such as phenacetin under controlled temperature and $\mathrm{pH}$.

\section{CONCLUSION}

Thermo-sensitive p(NIPAM-co-HPMet) hydrogels were synthesized using a free radical copolymerization.
FTIR spectra of xerogel and phenacetin confirm the performed synthesis. SEM micrographs show the porous surfaces of xerogels. An application of hydrogels for the controlled release was investigated by using the synthesized phenacetin. The largest amount of phenacetin $(272.2 \mathrm{mg} / \mathrm{g}$ xerogel) was released from the hydrogel with the minimum cross-linker ratio at $\mathrm{pH} 7.40$ compared to the released amount at $\mathrm{pH} 2.20$. The obtained thermo-sensitive $\mathrm{p}$ (NIPAM-co-HPMet) hydrogels provide good opportunities for their application as "in- 
Table 2. The phenacetin release kinetic parameters from p(NIPAM-co-HPMet) hydrogels at $37{ }^{\circ} \mathrm{C}$ and $p H 2.20$ and pH 7.40

\begin{tabular}{|c|c|c|c|c|}
\hline EGDM content, mol\% & $n$ & $k / \min ^{-1 / 2}$ & $D \times 10^{3} / \mathrm{cm}^{2} \min ^{-1}$ & $R^{2}$ \\
\hline \multicolumn{5}{|c|}{$\mathrm{pH} 2.2$} \\
\hline 0.5 & 0.0904 & 1.401 & 18.46 & 0.999 \\
\hline 1 & 0.142 & 0.989 & 10.00 & 0.926 \\
\hline 1.5 & 0.161 & 0.834 & 6.87 & 0.967 \\
\hline 2 & 0.212 & 0.861 & 4.25 & 0.952 \\
\hline 3 & 0.116 & 0.572 & 6.56 & 0.998 \\
\hline \multicolumn{5}{|c|}{$\mathrm{pH} 7.4$} \\
\hline 0.5 & 0.137 & 1.238 & 12.05 & 0.984 \\
\hline 1 & 0.109 & 1.314 & 13.57 & 0.993 \\
\hline 1.5 & 0.094 & 1.363 & 14.59 & 0.963 \\
\hline 2 & 0.119 & 1.068 & 8.97 & 0.981 \\
\hline 3 & 0.116 & 1.016 & 8.1 & 0.951 \\
\hline
\end{tabular}

telligent" drug carriers (e.g., phenacetin) with the controlled release.

\section{Acknowledgement}

This work is part of the project MNTR TR-34012 financed by the Ministry of Education and Science of the Republic of Serbia. The authors are grateful for the support provided by the Ministry.

\section{REFERENCES}

[1] T. Miyata, T. Uragami, K. Nakamae, Biomolecule-sensitive hydrogels, Adv. Drug Delivery Rev. 54 (2002) 79$-98$.

[2] M. Heskins, J.E. Guillet, Solution properties of poly(Nisopropylacrylamide), J. Macromol. Sci., A 2 (1968) 1441-1455.

[3] Y. Qiu, K. Park, Environment-sensitive hydrogels for drug delivery, Adv. Drug Delivery Rev. 53 (2001) 321-339.

[4] N.A. Peppas, R. Gurny, E. Doelker, P. Buri, Modelling of drug diffusion through swellable polymeric systems, J. Membr. Sci. 7 (1980) 241-253.

[5] N.A. Peppas, P. Bures, W. Leobandung, H. Ichikawa, Hydrogels in pharmaceutical formulations, Eur. J. Pharm. Biopharm. 50 (2000) 27-46.

[6] C.S. Satish, K.P. Satish, H.G. Shivakumar, Hydrogels as controlled drug delivery systems: Synthesis, crosslinking, water and drug transport mechanism, Indian J. Pharm. Sci. 68 (2006) 133-140.

[7] A. Suzuki, T. Tanaka, Phase transition in polymer gels induced by visible light, Nature 346 (1990) 345-347.

[8] S.J. Lue, J.-J. Hsu, T.-C. Wei, Drug permeation modeling through the thermo-sensitive membranes of poly $(\mathrm{N}$-isopropylacrylamide) brushes grafted onto micro-porous films, J. Membrane Sci. 321 (2008) 146-154.

[9] X. Huang, C.S. Brazel, On the importance and mechanisms of burst release in matrix-controlled drug delivery systems, J. Control. Release 73 (2001) 121-136.

[10] N.B. Milosavljević, N.Z. Milašinović, J.M. Filipović, M.T. Kalagasidis Krušić, Synthesis and characterization of co- polymer hydrogels of chitosan, itaconic acid and $\mathrm{N}$ isopropylacrylamide, Hem. Ind. 65 (2011) 657-666.

[11] C.M. Schilli, M. Zhang, E. Rizzardo, S.H. Thang, B.Y.K. Chong, K. Edwards, G. Karlsson, A.H.E. Muller, A new double-responsive block copolymer synthesized via RAFT polymerization: $\quad$ poly( $N$-isopropylacrylamide)-block-poly(acrylic acid), Macromolecules 37 (2004) 7861$-7866$.

[12] A. Martínez-Ruvalcaba, J.C. Sánchez-Díaz, F. Becerra, L.E. Cruz-Barba, A. González-Álvarez, Swelling characterization and drug delivery kinetics of polyacrylamide-co-itaconic acid/chitosan hydrogels, eXPRESS Polymer Letters 3 (2009) 25-32.

[13] S.Y. Kim, S.M. Cho, Y. M.O. Lee, S. J. Kim, Thermo- and $\mathrm{pH}$-responsive behaviors of graft copolymer and blend based on chitosan and $\mathrm{N}$-isopropylacrylamide. J. Appl. Polym. Sci. 78 (2000) 1381-1391.

[14] H.Y. Liu, X.X. Zhu, Lower critical solution temperatures of $\mathrm{N}$-substituted acrylamide copolymers in aqueous solutions, Polymer 40 (1999) 6985-6990.

[15] H.G. Schild, Poly( $N$-isopropylacrylamide) Experiment, theory and application, Prog. Polym. Sci. 17 (1992) 163-249 .

[16] T. Rustemeyer, S. De Ligter, B. M. E. Von Blomberg, P. J. Frosch, R. J. Scheper: Human T lymphocyte priming in vitro by haptenated autologous dendritic cells, Clin. Exp. Immunol. 117 (1999) 209-216.

[17] C.C.S Karlgard, N.S. Wong, L.W. Jones, C. Moresoli, In vitro uptake and release studies of ocular pharmaceutical agents by silicon-containing and p-HEMA hydrogel contact lens materials, Int. J. Pharm. 257 (2003) 141-151 .

[18] A. Karata, T. Baykara, Studies on release of ketorolac tromethamin and indomethacin from ophthalmic hydrogel inserts, J. Fac. Pharm, Ankara, 35 (2006) 255-268.

[19] W. Cai, E.C. Anderson, R.B. Gupta, Separation of lignin from aqueous mixtures by ionic and nonionic temperature-sensitive hydrogels, Ind. Eng. Chem. Res. 40 (2001) 2283-2288.

[20] H.M. Nizam El-Din, Characterization and caffeine release properties of $\mathrm{N}$-isopropylacrylamide/hydroxypropyl me- 
thacrylate, copolymer hydrogel synthesized by gamma radiation, J. Appl. Polym. Sci. 119 (2011) 577-585.

[21] S. llić-Stojanović, Lj. Nikolić, V. Nikolić, S. Petrović, M. Stanković, Process for synthesis of thermosensitive hydrogels and pharmaceutical applications, Patent P2010/0424 (Republic of Serbia)

[22] S.S. Ilić-Stojanović, Lj.Nikolić, V. Nikolić, M. Stanković, J. Stamenković, I. Mladenović-Ranisavljević, S.D. Petrović, Influence of monomer and crosslinker molar ratio on the swelling behaviour of thermosensitive hydrogels, Chem. Ind. Chem. Eng. Q. 18 (2012) 1-9.

[23] T. Ozeki, H. Yuasa, Y. Kanaya, Mechanism of medicine release from solid dispersion composed of poly(ethylene oxide)-carboxyvinyl polymer interpolymer complex and $\mathrm{pH}$ effect on medicine release, Int. J. Pharm. 171 (1998) 123-132.

[24] T. Ozeki, H. Yuasa, Y. Kanaya, Control of medicine release from solid dispersion through poly(ethylene oxide)-carboxyvinylpolymer interaction, Int. J. Pharm. 165 (1998) 239-244.
[25] T. Ozeki, H. Yuasa, Y. Kanaya, Control of medicine release from solid dispersion composed of the poly(ethylene oxide)-carboxyvinyl polymer interpolymer complex by varying molecular weight of poly(ethylene oxide), J. Control. Release 58 (1999) 87-95.

[26] T. Ozeki, H. Yuasa, Y. Kanaya, Controlled release from solid dispersion composed of poly(ethylene oxide)-carbopol interpolymer complex with various cross-linking degrees of Carbopol, J. Control. Release 63 (2000) 287-295.

[27] T. Ozeki, H. Yuasa, H. Okada, Controlled release of drug via methylcellulose-carboxyvinylpolymer interpolymer complex solid dispersion, AAPS Pharm. Sci. Technol. 6 (2005) E231-E236.

[28] M. Otsuka, Comparative particle size determination of phenacetin bulk powder by using Kubelka-Munk theory and principal component regression analysis based on near infrared spectroscopy. Powder Technol. 141 (2004) 244-250.

[29] H. Li, Smart Hydrogel Modeling, Springer, Heidelberg, 2009.

\section{IZVOD}

\section{POTENCIJALNA PRIMENA TERMOOSETUIVIH HIDROGELOVA ZA KONTROLISANO OTPUŠTANJE FENACETINA}

Snežana S. Ilić-Stojanović ${ }^{1}$, Ljubiša B. Nikolić ${ }^{1}$, Vesna D. Nikolić ${ }^{1}$, Jela R. Milić ${ }^{2}$, Slobodan D. Petrović ${ }^{3}$, Goran M. Nikolić ${ }^{4}$, Agneš J. Kapor ${ }^{5}$

${ }^{1}$ Univerzitet u Nišu, Tehnološki fakultet, Leskovac, Srbija

${ }^{2}$ Univerzitet u Beogradu, Farmaceutski fakultet, Beograd, Srbija

${ }^{3}$ Univerzitet u Beogradu, Tehnološko-metalurški fakultet, Beograd, Srbija

${ }^{4}$ Univerzitet u Nišu, Medicinski fakultet, Niš, Srbija

${ }^{5}$ Univerzitet u Novom Sadu, Prirodno-matematički fakultet, Departman za fiziku, Novi Sad, Srbija

(Naučni rad)

Brojna naučna istraživanja tokom poslednjih godina usmerena su na hidrogelove koji sadrže $N$-izopropilakrilamid (NIPAM) kao monomer. Hidrogelovi na bazi NIPAM-a sa 20 mol\% 2-hidroksipropilmetakrilata (HPMet), p(NIPAM-co-HPMet) sintetisani su korišćenjem različitih količina umreživača etilenglikoldimetakrilata (EGDM) i izvršena je njihova karakterizacija. FTIR spektar kserogela ukazuje na izvršenu sintezu iniciranjem pomoću radikala, a FTIR spektar fenacetina potvrđuje da je dobijen proizvod zadovoljavajuće čistoće. FTIR spektar kserogela sa fenacetinom ukazuju na izvršeno uklapanje fenacetina u unutrašnjost gela. SEM mikrografije nabubrelih i liofilizovanih uzoraka hidrogelova pokazuju da je njihova površina porozna, a uzorci sa uklopljenim fenacetinom pokazuju prisustvo fenacetina u porama hidrogela. Rezultati bubrenja pokazuju da termoosetljivi hidrogelovi na 20 ${ }^{\circ} \mathrm{C}$ ispoljavaju anomaliju u mehanizmu difuzije, bubrenje ne prati Fick-ov zakon, već je proces bubrenja kontrolisan difuzijom vode i relaksacijom polimernih lanaca. Transportni mehanizam bubrenja na $40{ }^{\circ} \mathrm{C}$ može se svrstati u tip III, sa vremenski nezavisnom kinetikom. Slično ponašanje pri bubrenju ovi hidrogelovi pokazuju u simuliranim fiziološkim uslovima ( $\mathrm{pH} 2,20$ i 7,40 na $37^{\circ} \mathrm{C}$ ). Potencijalna primena dobijenih hidrogelova kao nosača lekova sa kontrolisanim oslobađanjem fenacetina, kao model leka, ispitivana je pomoću HPLC metode. Rezultati pokazuju da je u prvih 24 sata otpuštena veća količina fenacetina na $37{ }^{\circ} \mathrm{C}$ u rastvoru $\mathrm{pH} 7,40$ (70-90\%) u odnosu na količinu otpuštenog fenacetina u rastvoru pH 2,20 (50-65\% od apsorbovane količine). Količina otpuštenog fenacetina srazmerno se smanjuje sa povećanjem gustine umreženja gelova. Proces otpuštanja lekovite supstance prati Fikov zakon difuzije za obe $\mathrm{pH}$ vrednosti. Dobijeni termoosetljivi hidrogelovi p(NIPAM-co-HPMet) pokazuju dobre mogućnosti za primenu kao „inteligentni“ nosači lekova (npr. fenacetina) sa kontrolisanom oslobađanjem.
Ključne reči: Termoosetljivi hidrogelovi • $N$-Izopropilakrilamid • 2-Hidroksipropilmetakrilat $\bullet$ Fenacetin 